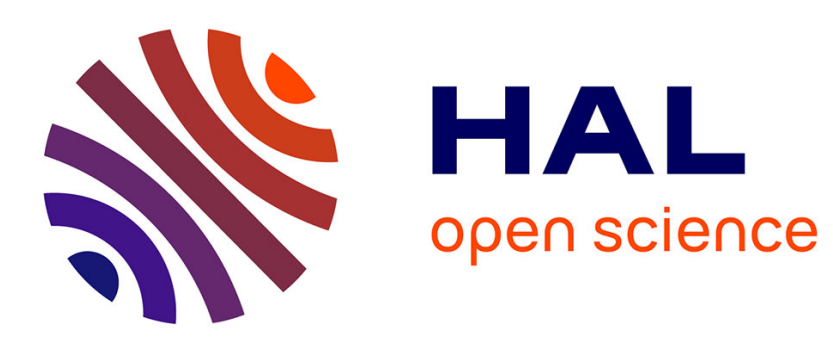

\title{
Laser materials on basis of disordered crystals with Ca3Ga2Ge4O14 structure
}

A. Nosenko, R. Leshchuk, V. Kravchishin

\section{To cite this version:}

A. Nosenko, R. Leshchuk, V. Kravchishin. Laser materials on basis of disordered crystals with Ca3Ga2Ge4O14 structure. Journal de Physique IV Proceedings, 1994, 04 (C4), pp.C4-455-C4-458. 10.1051/jp4:19944109 . jpa-00252558

\section{HAL Id: jpa-00252558 https://hal.science/jpa-00252558}

Submitted on 1 Jan 1994

HAL is a multi-disciplinary open access archive for the deposit and dissemination of scientific research documents, whether they are published or not. The documents may come from teaching and research institutions in France or abroad, or from public or private research centers.
L'archive ouverte pluridisciplinaire HAL, est destinée au dépôt et à la diffusion de documents scientifiques de niveau recherche, publiés ou non, émanant des établissements d'enseignement et de recherche français ou étrangers, des laboratoires publics ou privés. 


\title{
Laser materials on basis of disordered crystals with $\mathrm{Ca}_{3} \mathrm{Ga}_{2} \mathrm{Ge}_{4} \mathrm{O}_{14}$ structure
}

\author{
A.E. NOSENKO, R.Ye. LESHCHUK and V.V. KRAVCHISHIN \\ Lviv State University, Dragomanov Str. 50, Lviv 290005, Ukraine
}

The spectroscopic properties of $\mathrm{Ca}_{3} \mathrm{Ga}_{2} \mathrm{Ge}_{34} \mathrm{O}_{14}, \mathrm{Sr}_{3} \mathrm{Ga}_{3} \mathrm{Ge}_{4} \mathrm{O}_{14}$, $\mathrm{La}_{3} \mathrm{Ga}_{5} \mathrm{SiO}_{14}, \mathrm{Ia}_{3} \mathrm{Ga}_{5} \mathrm{GeO}{ }_{14}$ orystals doped with $\mathrm{Cr}^{3+}, \mathrm{Cr}^{4+}, \mathrm{Mn}^{3+}$ and $\mathrm{Ti}^{4+}$ ions have been investigated. In the $\mathrm{Ca}_{3} \mathrm{Ga}_{2} \mathrm{Ge}_{4} \mathrm{O}_{14}: \mathrm{Cr}$ crystals broadband continuous tunable within $0.77 \div 0.96 \mu \mathrm{m}$ stimulated emission of $\mathrm{Cr}^{3+}$ ions $\left({ }^{4} \mathrm{~T}_{2} \Rightarrow{ }^{4} \mathrm{~A}_{2}\right.$ channel) at room temperature has been obtained.

In modern physics and spectroscopy of laser crystals the grant attention to the search and investigations of disordered compounds with broad-band emission as potential tunable laser materials is paid. Among such crystals the compounds of $A_{3} B_{6} C_{x-6}{ }_{14}$ composition (Ca $\mathrm{Ga}_{2} \mathrm{Ge}_{4} \mathrm{O}_{14}$-type stmicture, space group P321) doped with $\mathrm{Cr}^{3+}$ Ions are distinguished, which are know as active elements of wavelength tunable lasers. 1,2 These acentre compounds open the way for the design of tunable solid-state lasers with frequency self doubling as well.

The $A_{3} B_{x} C_{6-x} O_{14}$ single crystals have been growth by Czochralsk1 method in platinum crucibles. ${ }^{2-4}$ The crystal structure of the $\mathrm{Ca}_{3} \mathrm{Ga}_{2} \mathrm{Ge}_{4} \mathrm{O}_{14}$ type is formed by tetrahedral layers orlented perpendicular to the c-axis, separated by inter-layers consisted of distorted Thomson cubes (3e positions with symmetry 2), occupled by large lons $\left(\mathrm{Ca}^{2+}, \mathrm{Sr}^{2+}, \mathrm{La}^{3+}\right)$, and octahedra (1a site w1th symmetry 32). 5 The tetrahedral layers include the tetrahedra of two types: the first ones are placed on third-order axis (2d positions with symmetry 3), and the others are grouped around the octahedra by the triple-axis mie ( $3 f$ sites with symmetry 2 ). The $\mathrm{X}$ - ray data analysis and spectral characteristics of $\mathrm{A}_{3} \mathrm{~B}_{\mathrm{X}} \mathrm{C}_{6-\mathrm{x}_{14}} \mathrm{O}_{14}$ crystals show that these crystals belong to disordered materlals.2.5 In $\mathrm{Ca}_{3} \mathrm{Ga}_{2} \mathrm{Ge}_{4} \mathrm{O}_{14}$ and $\mathrm{Sr}_{3} \mathrm{Ga}_{2} \mathrm{Ge}_{4} \mathrm{O}_{14}$ the disorder is due to the statistical occupation of $1 \mathrm{a}$ and $3 f^{4}$ positions by $\mathrm{Ga}^{3+}$ and $\mathrm{Ge}^{4+}$ Ions, in $\mathrm{Ia}_{3} \mathrm{Ga}_{5} \mathrm{SIO}_{14}$ and $\mathrm{Ia}_{3} \mathrm{Ga}_{5} \mathrm{GeO}$, the tetrahedral $2 a$ position are randomly occupled by $\mathrm{Ga}^{3+}$ and $\mathrm{Si}^{4+}\left(\mathrm{Ge}^{4+}\right)$ ions.

The absorption and Iuminescence spectra of the $\mathrm{Ca}_{3} \mathrm{Ga}_{2} \mathrm{Ge}_{4} \mathrm{O}_{14}$ type crystals were measured by conventionally methods within the temperature interval $80 \div 300 \mathrm{~K}$. The results obtalned are 11 lustrated 
In FIg.1 and summarized in Tabie. It was estabilshed, that in $\mathrm{Ca}_{3} \mathrm{Ga}_{2} \mathrm{Ge}_{4} \mathrm{O}_{14}$ the chromium and manganese ions being form the $\mathrm{Cr}^{3+}$ and $\mathrm{Mn}^{3+}$ substitutional centers in octahedral positions 1 a. The titanium impurity tons in $\mathrm{Ca}_{3} \mathrm{Ga}_{2} \mathrm{Ge}_{4} \mathrm{O}_{14}$ are in the valent state $\mathrm{Ti}^{4+}$ and the bands in the absorption and luminescent spectra (F1g.1) correspond to transition in the $\mathrm{O}^{2-} \Rightarrow \mathrm{Ti}^{4+}$ charge-transfer band. ${ }^{4}$

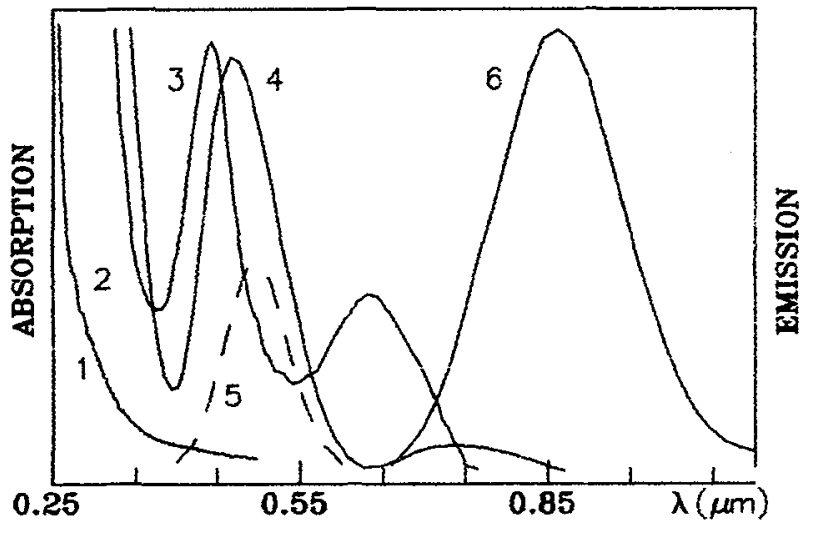

Fig. 1. Absorption (2-4) and Iuminescence $(5,6)$ spectra of $\mathrm{Ti}^{4+}(2,5)$, $\mathrm{Cr}^{3+}(3,6)$ and $\mathrm{Mn}^{3+}(4)$ ions in $\mathrm{Ca}_{3} \mathrm{Ga}_{2} \mathrm{Ge}_{4} \mathrm{O}_{14}$ crystal 11 - reference absorption spectra of undoped crystal). Dashed area indicates the laser-tuning range

In the absorption spectra of $\mathrm{Sr}_{3} \mathrm{Ga}_{2} \mathrm{Ge}_{4} \mathrm{O}_{14}: \mathrm{Cr}, \mathrm{La}_{3} \mathrm{Ga}_{5} \mathrm{SIO}_{14}: \mathrm{Cr}$ and $\mathrm{La}_{3} \mathrm{Ga}_{5} \mathrm{GeO}_{14}: \mathrm{Cr}$ crystals, besides the bands typlcal for $\mathrm{Cr}^{3+}$ Ions in the octahedral symmetry field, the another bands due to transitions of $\mathrm{Cr}^{4+}$ ions in octahedral positions were observed (see Table).

Table. Absorption and luminescence characteristios of chromium ions in $A_{3} \mathrm{~B}^{\mathrm{C}} 6-\mathrm{x}^{\mathrm{O}}{ }_{14}$ crystals.

\begin{tabular}{|c|c|c|c|c|c|c|c|c|}
\hline \multirow{4}{*}{ Crystal } & \multicolumn{6}{|c|}{ Peaks of absorotion bands ( $\mu \mathrm{m})$} & \multirow{3}{*}{\multicolumn{2}{|c|}{$\begin{array}{l}\text { Peaks of Iumi- } \\
\text { nescence bands } \\
\mathrm{Cr}^{3+} \text { ions }(\mu \mathrm{m})\end{array}$}} \\
\hline & \multicolumn{2}{|c|}{$\mathrm{Cr}^{4+}$} & \multicolumn{4}{|c|}{$\mathrm{Cr}{ }^{3+}$} & & \\
\hline & \multirow{2}{*}{$\begin{array}{l}{ }^{3} T_{1} \\
{ }^{3} T_{1}\end{array}$} & \multirow{2}{*}{$\begin{array}{l}{ }^{3} T_{1} \\
\Rightarrow^{3} T_{2}\end{array}$} & \multicolumn{2}{|c|}{${ }^{4} A_{2}{ }^{4}{ }^{T},(Y)$} & \multicolumn{2}{|c|}{${ }_{A_{2}} \Rightarrow{ }^{4} T_{2}(U)$} & & \\
\hline & & & E\|C & EıC & $E \| c$ & $E_{1 C}$ & ${ }^{4} T_{2} \Rightarrow{ }^{4} A_{2}$ & ${ }^{2} E \rightarrow{ }^{4} A_{2}$ \\
\hline $\mathrm{Ca}_{3} \mathrm{Ga}_{2} \mathrm{Ce}_{4} \mathrm{O}_{14}$ & & & 0.463 & 0.442 & 0.623 & 0.632 & 0.865 & 0.696 \\
\hline $\mathrm{Sr}_{3} \mathrm{Ga}_{2} \mathrm{Ce}_{4} \mathrm{O}_{14}$ & 0.390 & 0.495 & 0.445 & 0.435 & 0.603 & 0.618 & 0.830 & 0.694 \\
\hline $\mathrm{Ia}_{3} \mathrm{Ga}_{5} \mathrm{SiO}_{14}$ & 0.365 & 0.500 & & 0.423 & 0.630 & 0.633 & 0.910 & \\
\hline $\mathrm{Ia}_{3} \mathrm{Ga}_{5} \mathrm{GeO}_{14}$ & 0.360 & 0.495 & & 0.430 & 0.635 & 0.639 & 0.930 & \\
\hline
\end{tabular}

The absorption spectra are indicative of strong dichroism of crystals under investigation. So, for $\mathrm{Ca}_{3} \mathrm{Ga}_{2} \mathrm{Ge}_{4} \mathrm{O}_{14}: \mathrm{Cr}$ the relation 
of $\mathrm{Cr}^{3+}$ lons absorption bands intensities is: $Y_{\|}: Y_{1}: U_{\perp}: U_{\|}=1: 1.25$ : $0.47: 1.78$. Fano antiresonances are visible in absorption spectra of $A_{3} B_{x} C_{6-x} O_{14}:$ Cr crystals, due to superposition of ${ }^{2} \mathrm{E}$ and ${ }^{2} \mathrm{~T}$, energy levels w1th the quasi-continuum of the vibrationally broadened ${ }^{4} \mathrm{~T}_{2}$ level. In $\mathrm{A}_{3} \mathrm{~B}_{\mathrm{x}} \mathrm{C}_{6-\mathrm{x}_{14}} \mathrm{O}_{14}$ : cr crystals a photochromic effect has been found that is connected with the recharging of the impurity chromium ions $\left(\mathrm{Cr}^{3+} \Rightarrow \mathrm{Cr}^{4+}+e\right)$.

The emission of $\mathrm{Cr}^{3+}$ in $\mathrm{A}_{3} \mathrm{~B}_{6} \mathrm{C}_{\mathrm{X}-6} \mathrm{O}_{14}$ crystals is a mixture of the two types of transition: wide-band emission on ${ }^{4} \mathrm{~T}_{2} \Rightarrow^{4} \mathrm{~A}_{2}$ transition and $R$-line ( ${ }^{2} \mathrm{E} \Rightarrow{ }^{4} \mathrm{~A}_{2}$ channel) with its vibronic recurrences. Calculated of phonon energies are in good agreement with phonon frequencles in infrared and Raman spectra. The luminescence spectra in the $R$ region are characterized by significant line width $(\Delta=$ $40 \div 60 \mathrm{~cm}^{-1}$ ). The near-neighbours of $\mathrm{Cr}^{3+}$ Ions in crystals with $\mathrm{Ca}_{3} \mathrm{Ga}_{2} \mathrm{Ge}_{4} \mathrm{O}_{14}$ structure are represented by $\mathrm{six}$ cations in the tetrahedral $3 f$ position and three cations in the Thomson cube sites $3 e$, all nine are bonded with $\mathrm{Cr}^{3+}$ Ions $\nabla 1 \mathrm{a}$ oxygen 1ons. The second $\mathrm{Cr}^{3+}$ coordination sphere contains of the cation in $2 d$ tetrahedra and the cations in octahedra located above and below (along the c-axis) the or octahedron. The random occupation of $3 e, 1 a$ and $2 d$ positions by cations with different valency ( $\mathrm{Ga}^{3+}$ and $\mathrm{Ge}^{4+}$ or $\mathrm{Si}^{4+}$ ) could make the crystal field a title varying from one $\mathrm{cr}$ site to another resulting in inhomogeneous broadening of the $R$-iines.

The spectroscopic experiments with stimulated emission of $\mathrm{Cr}^{3+}$ Ions (vibronlc ${ }^{4} \mathrm{~T}_{2} \Rightarrow{ }^{4} \mathrm{~A}_{2}$ channel) in $\mathrm{Ca}_{3} \mathrm{Ga}_{2} \mathrm{Ge}_{4} \mathrm{O}_{14}$ crystals were carried out at $300 \mathrm{~K}$ using dispersion or nonselective optical resonator and a mibe laser, which was used for pumping of active elements. ${ }^{2}$ A strong dichrolsm of the sample absorption allowed to achieve an optimal (70-75\%) absorption level of pumping emission in the crystal by simple turn of the element around the resonator axis.

By using of nonselective laser resonator the dependence of energy parameters versus exc1tation level has been investigated (F1g.2). The threshold of generation relative the energy absorbed in the crystal was $\simeq 35 \mathrm{~mJ}$ with diferential output efficiency $\eta=12 \%$. The generation pulse was sinfted by 10 ns relative to the pumping pulse (FIg.2b). Duration of generation was $\approx 8 \mathrm{~ns}$. The broadband tunable stimulated emission has been realized within 0.77 : $0.97 \mu \mathrm{m}$ in dispersion resonator using the diffraction lattice as a selective element. 

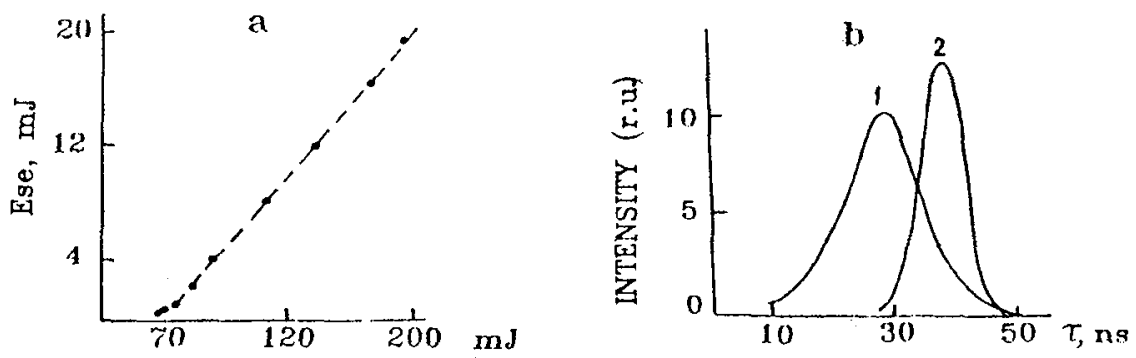

Fig.2. The energetio parameters of the laser on the basts of $\mathrm{Ca}_{3} \mathrm{Fa}_{2} \mathrm{Ge}_{4} \mathrm{O}_{14}: \mathrm{Cr}$ orystals va absorbed energy of exoltation (a) and the time profile of the pump (1) and generation (2) pulses (b).

The spectral region of Iuminescence and stimulated emission being obtained is not in agreement with data. 'These discrepancies, perhaps, are due to the statistical disorder in the cation sublatt1ce of the matrix. Sich crystallochemical pecullarstiy of the crystals under Investigation leads to nonreproduclbil1. iy of crystalline fleld in chromtum fons locations. The dependence of 1on energy 1evels on the crystalline fleld causes the changes of spectral characteristicg of $\mathrm{Cr}^{3+}$ lons in $\mathrm{Ca}_{3} \mathrm{Ga}_{2} \mathrm{Ge}_{4} \mathrm{O}_{14}$ matrlces being grown in somewhat varlous conditions. Therefore, in case of $\mathrm{ua}_{3} \mathrm{Ca}_{2} \mathrm{Ge}_{4} \mathrm{O}_{14}: \mathrm{Or}$ crystals changlng the technology of active media preparation one can obtain the extremely broad-band tumable slimulated enission $\mathrm{Cr}^{3+}$ Loni (from 0.7 t to $1.21 \mu \mathrm{m}$ ).

\section{References}

${ }^{1}$ A.A. Kamlnsk11, A.V. Butashin, A.A. DemLdov1ch, V.G. Kopter, B.V. M1ll anl A.A. Shkadarevich, Fiys. Stat. Sol. (a) 112, 197 (1939). ${ }^{2}$ A.P. Voltovich, A.F. Nosenko, A.G. Bazyiev, V.S. Kalinor, V.V. Kravohlohin and R.Ye. Ieshchuk, Zhurnal Irloladnoy Spectroscoptl 51,705 (1989).

${ }^{3}$ A. F. Noseniko, R.Ye. Jeshohuk and V.V. Kravohtshjn, Uleratngkt, ftztchesklt zhumal 34,1305 (1989).

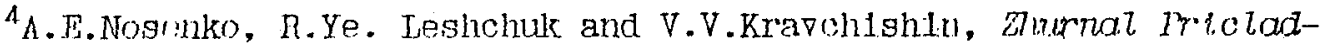
noy Spretroscopti. 54, 321 (1991).

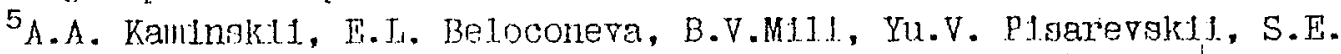
SarkLoov, I.M. Sllrestrova, A.B. Butashln and G.G. Khodzhabagyan, Miys. Slat. Sol. (a) 86, 345 (1984). 